\title{
The Assessment of the Main Climatic Conditions in North-West of Romania for Viticulture (1991-2013)
}

\author{
Florin Dumitru BORA ${ }^{1,3 *}$, Tiberia Ioana POP ${ }^{1}$, Claudiu Bunea ${ }^{1}$, Daniela POPESCU ${ }^{2}$, Maria \\ ILIESCU $^{2}$, Nastasia POP ${ }^{1 *}$ \\ ${ }^{1}$ Faculty of Horticulture, University of Agricultural Sciences and Veterinary Medicine Cluj-Napoca. \\ ${ }^{2}$ Research Station of Viticulture and Enology, Blaj, Romania. \\ ${ }^{3}$ Research Station of Viticulture and Enology, Târgu Bujor, Romania. \\ *)corresponding author, e-mail: nastpop@yahoo.com
}

BulletinUASVM Horticulture 72(2) / 2015

Print ISSN 1843-5254, Electronic ISSN 1843-5394

DOI:10.15835/buasvmcn-hort:11417

\begin{abstract}
Vines act as an indicator in relation with climate changes and they are particularly sensitive to temperature changes. The aim of this article is to present the climatic conditions and their interaction expressed by some viticultural indices and coefficients from North-West of Romania between 1991-2013. For characterize the three areas, (Maramureş ${ }^{1}$, Sălaj ${ }^{2}$ and Satu Mare $^{3}$ ) meteorological data from National Meteorological Agency has been used. The length of the growing season is within normal limits for the vine culture: 176 days in Maramureș, and 195 days in Sălaj and 184 days in Satu Mare. Comparing the thermal coefficient values $\left(C_{t}\right)$ of our country (situated between the values 16-19), we can conclude that all three areas have sufficient thermal resources for vine growth and fruition. The highest values of the real heliothermic index $\left(\mathrm{IH}_{\mathrm{r}}\right)$, hydrothermal coefficient $(\mathrm{CH})$ and wine bioclimatic index $\left(\mathrm{I}_{\mathrm{bcv}}\right)$ were recorded in Sălaj area: $1.5\left(\mathrm{IH}_{\mathrm{r}}\right)$; $1.4(\mathrm{CH}) ; 8.5\left(\mathrm{I}_{\mathrm{bcv}}\right)$. In contrast, with the lowest values: $\mathrm{IH}_{\mathrm{r}}=1.0$ and $\mathrm{I}_{\mathrm{bcv}}=3.5$, were registered in the area of Maramureș. Based on the results, it can be stated that vines can be cultivated in all three studied areas. The most favorable area is Sălaj, followed by Satu Mare, and the less favorable is the area of Maramureș, where vine culture falls more to amateurism.
\end{abstract}

Keywords: climatic conditions, viticultural indices and coefficients.

\section{Introduction}

Global warming has caused a disruption in the natural evolution of climatic factors in the vineyard's ecosystem, therefore summers have become extremely dry, autumns have become either cold, wet, or warmer than usual, while winters have become shorter, but with extremely low temperatures (Alexandru et al. 2014).

\section{Aims and objectives}

The main objective of this paper is to present the climatic conditions (temperature, insolation, rainfall) and their interaction, expressed by some viticultural indices and coefficients, from NorthWest of Romania, between 1991-2013, in three areas (Maramureș ${ }^{1}$, Sălaj ${ }^{2}$ and Satu Mare $^{3}$ ), but also to determine if this areas are friendly culture of the vine.

\section{Materials and methods}

In order to characterize the three areas, meteorological data from the National Meteorological Agency has been used. Based on their specific formulas, ecoclimatic indicators were determined, important for the growth and the fruition of vines, such as global thermal balance $\left(\sum \mathrm{t}^{\mathrm{o}} \mathrm{g}\right)$; active thermal balance $\left(\sum \mathrm{t}^{0} \mathrm{a}\right)$; useful thermal balance $\left(\sum \mathrm{t}^{0} \mathrm{u}\right)$; thermal coefficient $\left(C_{t}\right)$; annual and monthly rainfall amount; amount of hours of sunshine ( $\mathrm{ir}$ ) and real sunburn coefficient $\left(\mathrm{C}_{\mathrm{i}}\right)$. To get a broader picture on how climatic factors influence the growth and fruition 
Tab. 1. Climate data from the three studied areas, between 1991-2013

\begin{tabular}{|c|c|c|c|c|c|c|}
\hline \multirow{3}{*}{ Area } & \multirow{3}{*}{\multicolumn{2}{|c|}{ Studied elements }} & \multicolumn{3}{|c|}{ Specific } & \multirow{3}{*}{$\begin{array}{l}\text { Critical limits } \\
\text { for vines }\end{array}$} \\
\hline & & & \multirow{2}{*}{$\begin{array}{l}\text { Average } \\
\text { values }\end{array}$} & \multicolumn{2}{|c|}{ Extreme limits } & \\
\hline & & & & Min. & Max. & \\
\hline \multirow{12}{*}{$\mathrm{MM}^{1}$} & The vegetation period (days) & & 176 & 173 & 179 & $150-160$ \\
\hline & \multirow{4}{*}{ Thermal balance } & Global $\left(\sum \mathrm{t}^{0} \mathrm{~g}\right)$ & 2881 & 2878 & 2893 & $2100-2500$ \\
\hline & & Active $\left(\sum \mathrm{t}^{0} \mathrm{a}\right)$ & 2836 & 2831 & 2840 & $2300-2400$ \\
\hline & & Useful $\left(\sum \mathrm{t}^{0} \mathrm{u}\right)$ & 1157 & 1153 & 1161 & $850-1000$ \\
\hline & & Thermal coefficient $\left(\mathrm{C}_{+}\right)$ & 16.4 & 16.2 & 16.9 & $16-19$ \\
\hline & \multirow{2}{*}{ Insolation (hours) } & Real $\left(\sum\right.$ ir $)$ & 1172 & 1170 & 1176 & - \\
\hline & & Coefficient of insolation $\left(\mathrm{C}_{\mathrm{i}}\right)$ & 6.65 & 6.63 & 6.66 & - \\
\hline & \multirow{2}{*}{ Precipitations (mm) } & Total annual ( $(\mathrm{pp})$ & 817.5 & 789.3 & 826.3 & 500 \\
\hline & & Coefficient of precipitation (Cp) & 3.08 & 3.02 & 3.12 & - \\
\hline & \multirow{3}{*}{$\begin{array}{l}\text { The interaction of climatic } \\
\text { factors }\end{array}$} & Real heliothermic Index $\left(\mathrm{IH}_{\mathrm{r}}\right)$ & 1.0 & 0.9 & 1.1 & $1.35-2.70$ \\
\hline & & Hydrothermal coefficient (CH) & 2.4 & 2.2 & 2.5 & 0.7 \\
\hline & & Bioclimatic index $\left(\mathrm{I}_{\mathrm{hcv}}\right)$ & 3.5 & 3.4 & 3.9 & 5 \\
\hline \multirow{12}{*}{$\mathrm{SJ}^{2}$} & The vegetation period (days) & & 195 & 187 & 199 & $150-160$ \\
\hline & \multirow{4}{*}{ Thermal balance } & Global $\left(\sum \mathrm{t}^{0} \mathrm{~g}\right)$ & 3673 & 3670 & 3680 & $2100-2500$ \\
\hline & & Active $\left(\sum \mathrm{t}^{0} \mathrm{a}\right)$ & 3247 & 3242 & 3253 & $2300-2400$ \\
\hline & & Useful $\left(\sum \mathrm{t}^{0} \mathrm{u}\right)$ & 1539 & 1536 & 1546 & $850-1000$ \\
\hline & & Thermal coefficient $\left(\mathrm{C}_{+}\right)$ & 18.8 & 18.1 & 19.3 & $16-19$ \\
\hline & \multirow{2}{*}{ Insolation (hours) } & Real $\left(\sum\right.$ ir $)$ & 1514 & 1498 & 1530 & - \\
\hline & & Coefficient of insolation $\left(\mathrm{C}_{\mathrm{i}}\right)$ & 7.76 & 7.72 & 7.81 & - \\
\hline & \multirow{2}{*}{ Precipitations (mm) } & Total annual ( $(\mathrm{pp})$ & 506.4 & 499.6 & 512.3 & 500 \\
\hline & & Coefficient of precipitation (Cp) & 1.72 & 1.69 & 1.84 & - \\
\hline & \multirow{3}{*}{$\begin{array}{l}\text { The interaction of climatic } \\
\text { factors }\end{array}$} & Real heliothermic Index $\left(\mathrm{IH}_{r}\right)$ & 1.5 & 1.3 & 1.6 & $1.35-2.70$ \\
\hline & & Hydrothermal coefficient $(\mathrm{CH})$ & 1.4 & 1.3 & 1.9 & 0.7 \\
\hline & & Bioclimatic index $\left(\mathrm{I}_{\mathrm{bcv}}\right)$ & 8.5 & 8.2 & 8.9 & 5 \\
\hline \multirow{12}{*}{$\mathrm{SM}^{3}$} & The vegetation period (days) & & 184 & 182 & 193 & $150-160$ \\
\hline & \multirow{4}{*}{ Thermal balance } & Global $\left(\sum \mathrm{t}^{0} \mathrm{~g}\right)$ & 2989 & 2977 & 2996 & $2100-2500$ \\
\hline & & Active $\left(\sum \mathrm{t}^{0} \mathrm{a}\right)$ & 2936 & 2933 & 2954 & $2300-2400$ \\
\hline & & Useful $\left(\sum \mathrm{t}^{0} \mathrm{u}\right)$ & 1539 & 1536 & 1549 & $850-1000$ \\
\hline & & Thermal coefficient $\left(\mathrm{C}_{t}\right)$ & 16.2 & 16.1 & 16.9 & $16-19$ \\
\hline & \multirow{2}{*}{ Insolation (hours) } & Real ( $\sum$ ir) & 1394 & 1379 & 1399 & - \\
\hline & & Coefficient of insolation $\left(\mathrm{C}_{\mathrm{i}}\right)$ & 7.57 & 7.56 & 7.87 & - \\
\hline & \multirow{2}{*}{ Precipitations (mm) } & Total annual $\left(\sum p p\right)$ & 688.0 & 679.6 & 693.4 & 500 \\
\hline & & Coefficient of precipitation (Cp) & 2.36 & 2.34 & 2.42 & - \\
\hline & \multirow{3}{*}{$\begin{array}{l}\text { The interaction of climatic } \\
\text { factors }\end{array}$} & Real heliothermic Index $\left(\mathrm{IH}_{\mathrm{r}}\right)$ & 1.3 & 1.2 & 1.5 & $1.35-2.70$ \\
\hline & & Hydrothermal coefficient (CH) & 2.3 & 2.1 & 2.4 & 0.7 \\
\hline & & Bioclimatic index $\left(\mathrm{I}_{\mathrm{hcv}}\right)$ & 5.2 & 4.9 & 5.4 & 5.0 \\
\hline
\end{tabular}

of vines, the heliothermic index (HI), hydrothermal coefficient $(\mathrm{CH})$ and bioclimatic index $\left(\mathrm{I}_{\mathrm{bcv}}\right)$ were calculated (Țârdea et al. 1995).

\section{Results and Discussion}

The highest value of heat balance was recorded in Sălaj: global thermal balance $\left(\sum \mathrm{t}^{\mathrm{o}} \mathrm{g}\right)$ $3673^{\circ} \mathrm{C}$, active thermal balance $\left(\sum \mathrm{t}^{\mathrm{o}} \mathrm{a}\right) 3247^{\circ} \mathrm{C}$ and useful thermal balance $\left(\sum \mathrm{t}^{0} \mathrm{u}\right) 1539^{\circ} \mathrm{C}$. The 
highest coefficient of rainfall was recorded in Maramureş (Cp-3.08) and the lowest (Cp-1.72) was recorded in Sălaj area. The highest values of the real heliothermic index $\left(\mathrm{IH}_{\mathrm{r}}\right)$, hydrothermal coefficient $(\mathrm{CH})$ and wine bioclimatic index $\left(\mathrm{I}_{\mathrm{bcv}}\right)$ were recorded in Sălaj area $\left(\mathrm{IH}_{\mathrm{r}}=1.5 ; \mathrm{CH}=1.4\right.$ and $\mathrm{I}_{\mathrm{bcv}}=8.5$ ). In contrast, with the lowest values: $\mathrm{IH}_{\mathrm{r}}=1.0$ and $\mathrm{I}_{\mathrm{bcv}}=3.5$, were registered in the area of Maramureș, but in this area, the hydrothermal coefficient $(\mathrm{CH}=2.4)$ is higher than in the other two areas, which expresses excess moisture and that favors quantitative productions to the detriment of quality.

The results are influenced by study area, so that the best area for vines is $\mathrm{SJ}^{2}$, which is an area with a reputation, followed by $\mathrm{SM}^{3}$ also this area is a best for vines culture. Regarding the $\mathrm{MM}^{1}$ area, results indicate that in this area are less favorable for vine grow.

\section{Conclusion}

Based on the results, it can be stated that vines can be cultivated in all three studied areas. The most favorable area is Sălaj, followed by Satu Mare, and the less favorable is the area of Maramures, where vine culture falls more to amateurism.

Acknowledgments. This paper was published under the frame of European Social Fund, Human Resources Development Operational Programme 2007-2013, project no. POSDRU/159/1.5/S/132765.

\section{REFERENCES}

1. Alexandru LC, Rotaru L, Damian D, Nechita A (2004). The influence of climatic conditions on the vegetatice development of vine varieties grapes grown in the winegrowing center-Copou Iaşi. Bulletin UASMV Horticulture 71(2):195-200.

2. Țârdea C, Dejeu L (1995). Viticulture. Editura Didactică și Pedagogică. București. 